\title{
The Negative Impact of the Absence of Rules on Human Society: A Critical Reading of William Golding's Lord of the Flies ${ }^{(*)}$
}

\author{
Dr. Nouh Ibrahim Saleh Alguzo, \\ Associate Professor of English \\ Al-Imam Muhammad Ibn Saud Islamic University \\ Saudi Arabia
}

\begin{abstract}
This research paper studies the negative impact of the absence of rules on the life of humans through an analytical study of William Golding's novel Lord of the Flies. In his novel, Golding recounts the story of a group of English schoolboys who live as savages and killers because they refuse to obey the rules after they get isolated on a tropical island. The instinct of savagery is represented through the characters of the hunters who are longing for authority, while the instinct of civilization is represented through the character of Ralph, who attempts to keep the rules to escape the island. The hunters end up as savage-like creatures because they fail to understand the importance of rules and order to find a civil society. They become preys of evil that embody the darkness of the human soul, while the group of Ralph represents the bright side of civilized humans.
\end{abstract}

Keywords: civilization, savagery, rules, tropical island, English boys

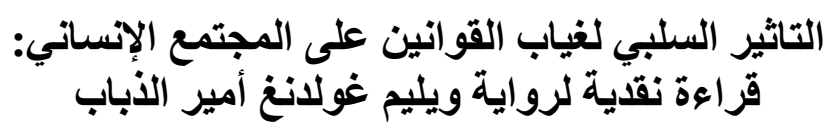

الملخص

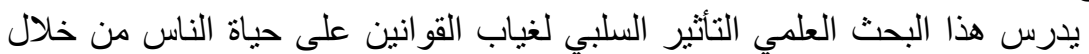

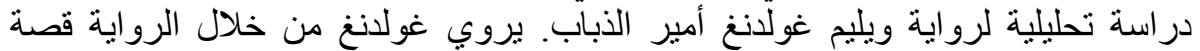

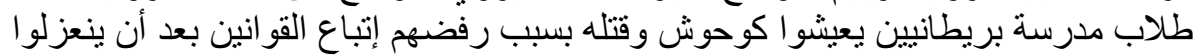

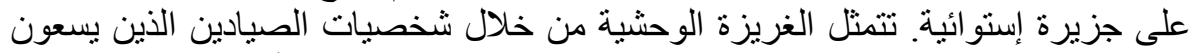
الى السلطة بينما يمثل غريزة الحضارة شخصية رالفين الفئ الذي يحاول أن يتبع القوانين لكي الكين

${ }^{(*)}$ Bulletin of the Faculty of Arts Volume 80 Issue 6 July 2020 
ينجو من الجزيرة. يتحول الصبادين الى مخلوقات شبيهة بالوحوش بسبب عدم إدراكهم

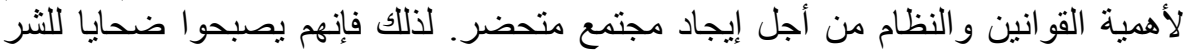

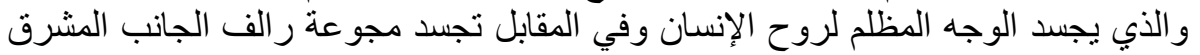

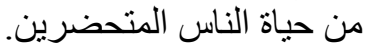

الكلمات المفتاحية: حضارة، وحشية، قو انين، جزيرة استو ائية، أو لاد بريطانيين

William Golding's novel Lord of the Flies (1954) recounts the story of a group of schoolboys stranded on a deserted island after their plane was shot during what it seems to be Third World War. Despite the disaster, the boys appear to be partially lucky because the tropical island provides them with plentiful fruits and shelter, and therefore would not die of hunger. However, the failure of the boys to obey the rules that they have already set to escape the island and their desire for power makes them turn into savages and kill one another. Golding says about the theme of the novel: "The theme is an attempt to trace the defects of society back to the defects of human nature" (qtd. in Martin 408). Despite the fact that Golding sees evil as part of human nature, scholars like Maurice McCullen link the evil of man to his inability to fight evil in society. McCullen says: "Golding sees evil within man, but he does not see that evil is also outside of man, omnipresent and multiform, and that man is forever too weak to combat it" (218). Other scholars like Peter Firchow focus on the religious dimension in the novel, "as one should be able to deduce from its title, it [the novel] also has a religious dimension" (131). This paper examines the consequences of the absence of order and rules on human life through discussing the life of the schoolboys in Golding's Lord of the Flies, who transform into savages and killers because of their failure to live a civilized life.

Golding emphasizes the importance of order and rules in the life of humans from the beginning of the novel. Ralph and Jack find conch that they decide to use to call the other boys for an assembly. Piggy speaks to Ralph: "We can use this [the conch] to call the others. Have a meeting. They'll come when they hear us" $(12)^{(1)}$. Piggy decides that they can use the conch to summon the other boys and 
have a meeting to discuss the possible ways to escape the island. No doubt that the conch in the novel represents a symbol of order, authority and civilization. After the boys vote for Ralph as a chief, the boy who holds the conch has the right to speak. James Morrison says: "Initially, the rules work. When Ralph simply holds up the conch, there is silence" (189). However, the longing of Jack, the competitor of Ralph, for power and his constant attempts to break the rules make the conch lose its symbolic significance.

The rationality of Ralph and his treatment of the boys in a good manner makes him a successful leader. Ralph does not exclude his political competitor, Jack, from taking responsibility in the attempt of rescuing the boys. Ralph names Jack as leader of the hunters, who are responsible for finding meat to the boys as well as keeping the signal fire at the top of the mountain to be seen by passing ships. $\mathrm{He}$ makes rescuing the boys his top priority and decides to explore the surrounding. Ralph speaks to the boys:

Listen, everybody. I've got to have time to think things out. I can't decide what to do straight off. If this isn't an island we might be rescued straight away. So we've got to decide if this is an island. Everybody must stay round here and wait and not go away. Three of us--if we take more we'd get all mixed, and lose each other-three of us will go on an expedition and find out. (21)

Despite the absence of adults on the island, Ralph always tries to do the right thing and to take things seriously unlike most of the other boys who keep playing and searching for fruits. Peter Firchow notes, "the breakup of what initially seems like a juvenile utopia is caused by the insistence of would-be adults like Piggy (and to a lesser extent, Ralph) that 'fun' is not enough, or even that 'fun' poses a danger that needs to be eliminated" (137). Therefore, as a leader of the boys, Ralph avoids being playful and divides the duties on the boys to look after themselves and find a way to escape the island.

Golding highlights the importance of having rules and obeying them to build a civilized society. Jack asserts in the novel that "we'll have rules ... Lots of rules!" (34). And when Ralph announces the 
importance of keeping the signal fire at the top of the mountain to be rescued by passing ships and the importance of having rules, "We've got to have special people for looking after the fire. Any day there may be a ship out there ... and if we have a signal going they'll come and take us off. And another thing. We ought to have more rules" (45), Jack replies, "I agree with Ralph. We've got to have rules and obey them. After all, we're not savages. We're English, and the English are best at everything. So we've got to do the right things" (45). After this speech by Jack, one would expect that the British boys in the novel would behave in a respectful manner to one another rather than "show[ing] animalistic traits" (Carter 54). David Spitz argues that "[Golding] chose British schoolboys because, as he said, he knew them best - he had himself been a schoolmaster for many years - and because they were the stuff of which British gentlemen were made; hence it was to be expected that they would know how to conduct themselves" (23). It would be important to note here that based on his experience as a schoolmaster, Golding wants from the English schoolboys to show a better example than the boys in his novel. It seems that Golding is sending a message to his people that the juveniles who act in such a way would fail to build a civilized society.

Despite the constant advices of Ralph about the importance of keeping the rules, Jack and his hunters prefer to live a chaotic life, without rules, on the island. The boys succeed in igniting the signal fire by using the glasses of Piggy to focus sunlight, but this fire takes the forest and kills one of the boys because Jack prefers going hunting rather than doing his duty of watching the fire. No doubt that the death of one of the little boys makes the fire lose its significance as a signal fire to rescue the boys and becomes a destructive one. Peter Firchow states, "civilization, in the form of fire, is not only fragile, it is also profoundly dangerous, both on the island and off it" (152). Jeanne Delbaere-Garant also comments on the misuse of the fire by the boys, "meant as a signal fire for passing ships or planes it becomes, through misuse, a wild beast with a life of its own which invades the whole place, kills the little boy with the mulberry-colored birthmark, and threatens to destroy them all" (78). Furthermore, the boys miss a 
passing ship because the hunters ignore their responsibility of keeping the smoke up in the air. No doubt that the ship is the way of the boys to civilization away from the savage life they are leading on the island. Therefore, by preferring to go hunting and kill pigs rather than watching the fire, the boys become preys of evil dominated by their savage instincts.

Golding presents pessimistic outlook on life by showing that evil, represented through the characters of Jack and his hunters, rules over goodness, represented through the characters of Piggy, Ralph and Simon. Golding introduces Piggy as a scholar, who is always ignored by others because of his obesity. Maurice McCullen comments, "Golding thought of Piggy as the embodiment of the scientist and imagined him rambling around the island in a laboratory coat" (219). Piggy laments the ignorance of the hunters and loses his temper for ignoring him,

I got the conch! Just you listen! The first thing we ought to have made was shelters down there by the beach. It wasn't half cold down there in the night. But the first time Ralph says 'fire' you goes howling and screaming up this here mountain. Like a pack of kids! ... How can you expect to be rescued if you don't put first things first and act proper? (48)

Piggy refuses to accept the wicked life of the hunters, and therefore he becomes an object of mockery. However, Piggy remains one of few rational and thoughtful boys on the island that is willing to change the world. David Spitz reads Piggy as a philosopher,

Piggy I take to be Socrates, the voice of reason ... He alone shows marks of intelligence; he can think; he has brains. He not only thinks; he knows himself as well as other men ... When he wears his spectacles he can see; he is like Plato's philosopher who has emerged from the cave. Those same spectacles not only shed light; they make possible the lighting of the fire which is meant to be seen. And when he is deprived of those spectacles, he loses his rationality too. He has a sense 
of what is required for society. He calls for order and justice ... and appeals to what is right. (26)

Piggy stands for the philosopher in Golding's novel because he uses logic and reason to save other boys from darkness. He suggests to make a list of the names of younger boys, to make shelters by the beach, and it was the spectacles of Piggy that were used to produce fire that may rescue the boys.

Golding emphasizes the importance of ethics and altruism in society, represented through the character of Simon in the novel. While characters like Roger struggle to satisfy their "sadistic impulses" (Firchow 144) through throwing stones at the little boys to frighten them and destroy their castles that they build by the beach, Simon works for the goodness of the community through helping the little boys with the fruits they cannot reach. Golding seems to be suggesting that people like Simon who epitomize discipline, goodwill, and helpfulness can only build community while people who behave like Roger will cause anarchy and destruction.

The character of Jack proves that his desire for authority and satisfying his impulses are more important to him than order and rules. After the constant speeches of Ralph about the rules, Jack replies in an agitated manner, "Bollocks to the rules! We're strong--we hunt! If there's a beast, we'll hunt it down! We'll close in and beat and beat and beat" (104). Jack announces that the rules are useless and starts frightening the little boys with the beast and that he would be the only one to save them if the beast appears. He attempts to substitute Ralph as a leader by convincing the boys that Ralph is coward and will not be able to protect them from the beast. Jack declares that "[Ralph] isn't a proper chief" (147). Maurice McCullen suggests that when the authority moves to Jack, the boys are left with nothing but savagery. McCullen says: "having rejected reason, man is left with only savagery and force - with Jack the authoritarian man" (224). Jack is the opposite of Ralph. While Ralph represents wisdom and reason, Jack stands for ignorance and rebellion. Golding suggests that Jack does not fit for leadership: "The trouble was, if you were a chief you had to think, you had to be wise. And then the occasion slipped by so 
that you had to grab at a decision. This made you think; because thought was a valuable thing, that got results" (87). The irresponsible actions of Jack and his lack of prudence imply that he will rule through force rather than wisdom and reason. Golding attempts to trace the evil nature of humans after World War II and their desire to destroy one another in a world that seems to be lacking order and rules. David Spitz comments,

[Golding's] method is to create a civilization out of innocence, to detach a group of the best of our very young and to put them into a state of nature, there to found a civil society on such principles of decency as seem to them appropriate, and to follow with a close and careful eye their inevitable course of destruction. His evidences are the events that constituted that course. (29)

Golding seems to be suggesting that the life of the innocent boys on the island who fail to find "a civil society" is no better than the world of adults away from the island who are engaged in a destructive war killing one another for the sake of power.

The hunters on the island lose their human identity once they smear their faces with charcoal so they cannot be seen by animals and commit their crimes by attacking the group of Ralph. Jack orders the hunters to paint their faces before they attack Ralph and snatch fire, "we'll raid them and take fire. There must be four of you; Henry and you, Robert and Maurice. We'll put on paint and sneak up; Roger can snatch a branch while I say what I want" (159). The condition of the boys after they transform into savage-like creatures is described as following,

They were dirty, not with the spectacular dirt of boys who have fallen into mud or been brought down hard on a rainy day. Not one of them was an obvious subject for a shower, and yet--hair, much too long, tangled here and there, knotted round a dead leaf or a twig; faces cleaned fairly well by the process of eating and sweating but marked in the less accessible angles with 
a kind of shadow; clothes, worn away, stiff like his own with sweat, put on, not for decorum or comfort but out of custom; the skin of the body, scurfy with brine. (126)

Once the hunters start to lose restraint, they establish new identity as killers and criminals. James Morrison says: "The mask was a thing of its own, behind which Jack hid, liberated from shame and selfconsciousness" (190). The fact that when Jack hides his face with charcoal, he relinquishes his human identity and substitutes it with the identity of a savage, who loses control over his actions and feels no shame to commit crimes. Kimlyn Bender comments on the freedom that the mask creates,

Jack and the hunters in Lord of the Flies find a freedom behind the mask that allows them to commit savage acts that otherwise, ostensibly, their moral consciences would not allow. Of all of humanity's contrivances, the mask creates the greatest freedom; it enables the extension of the will into the immoral, simultaneously freeing the individual from the moral conscience and personal responsibility. The mask creates a false identity that confuses and hinders attempts to determine responsibility and administer justice. (161)

As a schoolmaster who had experience with English schoolboys, Golding seems to be suggesting that it would be the responsibility of society to establish ethics and morals within the boys. Bender notes, "the challenge of ethics today is to focus not on the masks but on the individuals behind them and to reawaken within the individual a renewed sensitivity to the moral conscience, bringing every area of life and action under its guidance" (162). This implies that children would lose their innocence if they were left open to evil that may produce anarchy in society.

The savagery of the hunters can be seen clear in the way they kill a sow and cut her head to impale on a stake as an offering to the beast. This savagery when they kill the sow is described as following: 
This dreadful eruption from an unknown world made her frantic; she squealed and bucked and the air was full of sweat and noise and blood and terror. Roger ran round the heap, prodding with his spear whenever pigflesh appeared. Jack was on top of the sow, stabbing downward with his knife ... The sow collapsed under them and they were heavy and fulfilled upon her. (157158)

This horrible image of killing the sow reminds us with the human need for self-restraint and civilization. These hunters lose discipline because of their failure to maintain their former civilized life as English schoolboys. Therefore, they believe that the head of the sow, the lord of the flies, can protect them from evil. Minnie Singh comments, "Lord of the Flies proposes its own version of irresponsible authority in the terrifying figure of Jack" (209). Jack represents the totalitarian regime that has absolute power and punishes the citizens for no clear reason. Therefore, the hunters move from order to chaos because of the irresponsible actions of Jack. The current condition of the boys reminds us with the first time they land on the island with an abundance of fruits and water that seemed to be a perfect place to live together as a community. However, the transformation of the boys into killers and savages who do not hesitate to set the island on fire and kill one another change the island into hell. Peter Firchow speaks about the island, "it's only gradually that the good island becomes a bad island, that utopia turns into dystopia" (136). This signifies the importance of order in preventing outlaws like Jack from causing harm to society only to satisfy their personal interests of having authority.

Golding highlights the idea that evil lies within the human soul rather than outside man. In the novel, the speech of the lord of the flies that is covered with insects to Simon establishes the fact that when someone loses control over his actions, he becomes susceptible to evil. The lord of the flies speaks to Simon, "fancy thinking the Beast was something you could hunt and kill! ... You knew, didn't you? I'm part of you? Close, close, close! I'm the reason why it's no go? Why 
things are what they are?" (167). This most notable passage in the novel emphasizes the destructive role that a tyrannical regime, represented through the character of Jack, can play in the life of humans. Simon realizes that there is no beast on the island after climbing the mountain and seeing the dead parachutist that the boys mistake for the beast. Therefore, the beast lies within the boys and it would be essential to get rid of this human ferocity to establish civil society. The fact that evil becomes part of man makes it impossible to escape the inner fears. Maurice McCullen disagrees with the idea that evil is part of human nature, "evil lies in Western culture" (221). However, it would be erroneous to link evil to Western culture when evil lies within some people from different parts of the world.

The fact that Simon frees the dead parachutist of the tree before his murder by the boys, who mistake him for the beast, destroys any evidence about the non-existence of the beast. Ralph announces, "I'm frightened. Of us. I want to go home. Oh God, I want to go home" (184). The boys never feel safe on the island not because of an outside threat but because of the inner fear of their evil nature. David Spitz links the story of Simon coming down from the mountain to the story of Moses, "like Moses, then, he comes down from the mountain bearing the truth - which in Simon's case is that the beast is Man himself, the boys' (and man's) own natures. But when he comes out of the darkness, bringing the truth, he is not heard - for what ordinary man can live with so terrible an understanding?" (25). Therefore, by murdering Simon before they discover his true identity, the boys seem unwilling to see the truth. Mary Carter notes, "Golding urge[s] us to know ourselves, and yet seem[s] to imply that such knowledge is beyond our ability, simply because we are human" (54). Golding announces that the children are not exempt from the violations of savagery,

Man is a fallen being. He is gripped by original sin. His nature is sinful and his state perilous. ... I looked round me for some convenient form in which this thesis might be worked out, and found it in the play of children. I was well situated for this, since at this time I 
was teaching them. Moreover, I am a son, brother, father. I have lived for many years with small boys, and understand and know them with awful precision. I decided to take the literary convention of boys on an island, only make them real boys instead of paper cutouts with no life in them; and try to show how the shape of the society they evolved would be conditioned by their diseased, their fallen nature. (Golding, "Fable" 88)

Golding attempts to introduce the sinful nature of man through the story of the English schoolboys, who seem as innocent and harmless when they first arrive to the island and end up as cruel and violent creatures, who are willing to satisfy their animalistic desires.

The murder of Piggy and the break of the conch, with the rock that Roger rolls down the mountain, represent the end of reason, civilization and order. The break of the conch symbolizes the fragility of civilization on the island and the fact that the savage instinct of the boys rules over reason. Minnie Singh comments on the savagery of Roger, "he [Roger] represents the erosion of restraint, the return to a sort of Stone Age" (206). This return to the "Stone Age" can be seen when the hunters put the island on fire to force Ralph, who was considered an outlaw, out. However, this destructive fire is the fire that saves Ralph from the hunters when a British naval officer notices the smoke. The British naval officer addresses the boys, "I should have thought that a pack of British boys-you're all British, aren't you?--would have been able to put up a better show than that--I mean" (238). While the English officer chastises the boys for the loss of innocence, we realize that that he is not leading a better life, especially when he is part of a devastating war that is running outside the island.

In conclusion, Golding highlights the negative impact of savagery and the absence of rules on human society through recounting the story of the English schoolboys, who prefer to hunt and kill rather than live as a community. As a schoolmaster, Golding seems to be suggesting that it is the responsibility of society to instill ethics and morals within schoolboys. The hunters lose innocence and 
end up as killers because they refuse to obey the rules and find a civil society. While the hunters represent the savage instinct and barbarity, characters like Ralph represent the need of humans to civilization and rules. Golding criticizes the darkness of the human soul, represented through the characters of the hunters, while at the same time shows the bright side of civilized beings, represented through the group of Ralph.

NOTE

All quotes from the primary text are taken from the same edition. See documentation in references 


\section{References}

Bender, Kimlyn. An Ethical Compass: Coming of Age in the 21st Century. New Haven: Yale University Press, 2010.

Carter, Mary Ruthe. "Peter Brueghel and William Golding." The English Journal 73.7 (1984): 54-55.

Delbaere-Garant, Jeanne. "Rhythm and Expansion in Lord of the Flies." William Golding: Some Critical Considerations. Ed. Jack I. Biles and Robert O. Evans. Kentucky: University Press of Kentucky, 1978.

Firchow, Peter Edgerly. Modern Utopian Fictions from H. G. Wells to Iris Murdoch.

Washington: Catholic University of America Press, 2007.

Golding, William. "Fable." In Golding, The Hot Gates and Other Occasional Pieces.

New York: Harcourt, Brace, \& World, 1965.

---. Lord of the Flies. Beirut: York Press, 2002.

Martin, Jerome. "Symbol Hunting Golding's Lord of the Flies." The English Journal 58.3 (1969): 408-413.

McCullen, Maurice L. "Lord of the Flies: The Critical Quest." William Golding: Some Critical Considerations. Ed. Jack I. Biles and Robert O. Evans. Kentucky: University Press of Kentucky, 1978.

Morrison, James V. Shipwrecked: Disaster and Transformation in Homer, Shakespeare, Defoe, and the Modern World. Michigan: University of Michigan Press, 2014.

Singh, Minnie. "The Government of Boys: Golding's Lord of the Flies and Ballantyne's Coral Island." Children's Literature 25 (1997): 205-213.

Spitz, David. "Power and Authority: An Interpretation of Golding's Lord of the Flies." The Antioch Review 30.1 (1970): 21-33. 